\title{
Combined RAAS and NEP Inhibition
}

\section{Giuseppe Vergaro ${ }^{1}$, Marco Metra²}

1. Fondazione Toscana Gabriele Monasterio, Pisa, Italy

2. Professor of Cardiology, Department of Medical and Surgical Specialties, Radiological Sciences, and Public Health, University of Brescia, Spedali Civili, Brescia Italy

\section{Corresponding author:}

Marco Metra, Department of Medical and Surgical Specialties,

Radiological Sciences, and Public Health,

University of Brescia, Spedali Civili, Brescia Italy.

Email: metramarco@libero.it

\begin{abstract}
The neurohormonal model of HF has provided the rationale for the use of drug classes blocking the effectors of both the RAAS and SNS at different sites, including angiotensin-converting enzyme inhibitors (ACEI), angiotensin receptor blockers (ARB), mineralocorticoid receptor antagonists (MRA), and beta-blockers. Combined NEP and ACE blockade although unsuccessful with omapatrilat in the OVERTURE trial, found success with sacubitril/valsartan in the Paradigm-HF trial. The results of PARADIGM-HF trial represent one of the most significant breakthroughs in the management of HF of the last decade, representing a shift from neurohomonal antagonism to neurohormonal modulation.
\end{abstract}

Keywords: heart failure; sacubitril/vlasartan; neurohormonal antagonists

Citation: $\quad$ Vergaro G and Metra M. Combined RAAS and NEP Inhibition. International Cardiovascular Forum Journal 2019;17:29-33, DOI: 10.17987/icfj.v17i0.601

\section{Introduction \\ Neurohormonal activation in heart failure}

After the pivotal observations by Cohn et al. concerning the significance of increased circulating concentrations of neurohormonal markers norepinephrine, plasma renin activity, and arginine vasopressin in patients with congestive heart failure (HF)[1], the neurohormonal model has become the main interpretative framework of the pathophysiology of HF in the last three decades.[2] Activation of neuroendocrine systems (the reninangiotensin-aldosterone system - RAAS - and the sympathetic nervous system - SNS) after an initial insult to the cardiovascular system initially plays a compensatory role to maintain circulatory homeostasis, by supporting cardiac output and promoting peripheral vasoconstriction. Prolonged overactivation of such axes over time, however, causes maladaptive cardiac remodelling and myocardial injury, thereby initiating a vicious cycle finally which can lead to the development of the overt HF syndrome.[3]

The effects of RAAS and SNS activation are only partly counterbalanced by the natriuretic peptide (NP) system, mainly involving atrial and B-type NP (ANP and BNP, respectively). These NP's confer natriuretic, diuretic, vasodilative, anti-fibrotic and anti-hypertrophic actions, mediated through interaction with NP receptors A (NPR-A) and B (NPR-B), and via an increase in the second messenger cGMP.[4] Whilst ANP is largely produced by atrial tissue, BNP is synthetized and released by ventricular myocytes from its precursor proBNP. Upon release into the circulation, proBNP is cleaved in equal proportions into the biologically active 32 amino acid BNP, and into the biologically inactive 76 amino acid N-terminal fragment (NT-proBNP). BNP is cleared from the plasma by binding to NP receptor type C (NPR-C), and through proteolysis by neutral endopeptidase (neprilysin, NEP). In contrast, NT-proBNP is mainly cleared by renal excretion[5] and is not a substrate for NEP. NEP is a highly non-specific enzyme, exerting hydrolytic effects on several vasoactive peptides other than BNP, including substance $P$ and bradykinin (both with vasodilative actions) and endothelin-1 and angiotensin I and II (with vasoconstrictor effects). [6,7]

The neurohormonal model of HF has provided the rationale for the use of drug classes blocking the effectors of both the RAAS and SNS at different sites, including angiotensin-converting enzyme inhibitors (ACEI), angiotensin receptor blockers (ARB), mineralocorticoid receptor antagonists (MRA), and betablockers. Each of these classes has provided prognostic benefit in terms of mortality and hospitalization reduction in HFrEF and related syndromes, in many cases additional to that achieved by the other classes, the exception being additional ARB on top of ACE inhibition.[8] Despite major advances in HF management, morbidity and mortality remains high, and neurohormonal antagonism incomplete, due to breakthrough phenomena.[9-11] Furthermore, until relatively recently, the therapeutic approach to HF has been restricted to the blunting of the "bad arm" of neurohormonal activation (mainly represented by RAAS and SNS over-activation), whilst no pharmacological agent was available to potentiate the "good arm", represented by the NP system. 
This may have restricted our ability fully to restore normal neurohormonal balance.

\section{Angiotensin-converting enzyme inhibitors and angiotensin II type I receptor blockers}

Activation of RAAS plays a crucial role in the pathophysiology and clinical presentation of HF. It can be a consequence of renal hypoperfusion, where a decrease in filtered sodium reaching the macula densa in the distal tubule results in an increased sympathetic stimulation of the kidney, leading to the renin release from the juxtaglomerular apparatus. Renin cleaves circulating angiotensinogen to angiotensin I, which is then converted by angiotensin converting enzyme (ACE) to the biologically active octapeptide angiotensin II. Finally, angiotensin II stimulates aldosterone production in the adrenal glands. The integrated RAAS acts both in the bloodstream in a classical endocrine mode, and within tissues in paracrine and autocrine modes.[12] After the development of the first clinically available orally active ACE-I, captopril, which was shown to reduce mortality in patients with left ventricular (LV) systolic dysfunction following acute myocardial infarction,[13] a number of other ACE-Is have been tested in randomized clinical trials and have been demonstrated the ability to attenuate ventricular remodelling, to increase ventricular function, and to improve mortality and morbidity in patients with HFrEF.[14]

As most detrimental effects of angiotensin II are mediated by its type 1 receptor, oral ARBs were later developed for clinical use in HF, the first of them being losartan. Unlike ACEls, ARBs do not inhibit the degradation of kinins, and are therefore less frequently associated with angioedema and cough, which are more common in patients receiving ACE-I. A summary of existing evidence on the effects of ACE-Is and ARBs in patients with HF and LV dysfunction is presented in Table 1.

According to the latest European Society of Cardiology (ESC) guidelines, ACEls (captopril, enalapril, lisinopril, trandolapril and ramipril) are recommended, in addition to a beta-blocker, in symptomatic patients with HFrEF to reduce the risk of HF hospitalization and death (Class I, level of evidence A), as well as in patients with asymptomatic LV systolic dysfunction and a history of myocardial infarction to prevent or delay the onset of $\mathrm{HF}$ and prolong life (Class I, level of evidence A) and in patients with asymptomatic LV systolic dysfunction without a history of myocardial infarction to prevent or delay the onset of HF (Class I, level of evidence B).[15]

As the evidence supporting the clinical benefit of ARBs in HF is less strong than for ACE-Is, their use (candesartan, valsartan and losartan) should be limited to HFrEF patients who are not able to tolerate an ACE-I because of serious side-effects (Class I, level of evidence B).[15]

Although there is potential for synergism between dual RAAS blockade, the ARB valsartan did not reduce mortality (while it decreased hospitalization for HF) in patients with $\mathrm{HFrEF}$ receiving background ACE inhibition.[16] As safety concerns were also raised, the combination of $A C E l s$ and $A R B s$ should be restricted to a highly selected subset of patients in whom other therapeutic options are not feasible (e.g. intolerance to MRA).[15]

\section{Sacubitril/valsartan: from neurohormonal antagonism to modulation Neprilysin as a therapeutic target}

The net biological effect of NEP is the sum of the inhibitory actions on systems with either vasodilative and vasoconstrictor properties. Therefore, while NEP inhibition should increase circulating NP levels, the corresponding increase in angiotensin II and endothelin-1 may mitigate NP-induced natriuresis, diuresis, anti-fibrotic and anti-hypertrophic effects. Isolated pharmacological NEP inhibition has thus never reached clinical use as a valuable option in the treatment of cardiovascular diseases.[17,18]

Combined NEP and ACE blockade was attempted by means of pharmacological agents with double inhibitory properties, the most widely tested of them being omapatrilat. In the OVERTURE trial, omapatrilat reduced the risk of cardiovascular death and of readmission for HF by approximately $10 \%$ compared to enalapril. [19] However, omapatrilat was associated with an increase in clinically relevant episodes of angioedema, likely due to the increase in circulating bradykinin levels following the combined inhibition of ACE and NEP, both acting as major enzymatic pathways of bradykinin degradation.[20]

Following these clinical and pathophysiological consideration, interest has shifted to the development of a combined NEP and angiotensin II receptor type 1 (AT1) inhibitor. The main advantage of such a strategy, further to a minor influence on bradykinin concentration, is due to the inhibition of the effects of angiotensin II generated through ACE-independent pathways and to a selective action on AT1, leaving unaffected the interaction of angiotensin II with AT2 receptor (associated to vasodilation and improvement in cardiac and vascular function).[21-23]

\section{Clinical pharmacology of sacubitril/valsartan}

Sacubitril/valsartan is the first in class of angiotensin receptor/ neprylisin inhibitors (ARNI), providing simultaneous inhibition of NEP and of RAAS. Sacubitril/valsartan (also known as LCZ696) is a novel single molecule comprising molecular moieties (in 1:1 ratio) of AHU377 (sacubitril), a prodrug which is further metabolized in the liver to LBQ657 (sacubitrilat), the biologically active NEP inhibitor, and valsartan, an AT1 receptor antagonist.[24-26]

With the use of sacubitril/valsartan a blockade of angiotensin II is achieved, and, at the same time, a decrease in the breakdown of endogenous NP potentiates their vasodilative, natriuretic, diuretic and anti-remodelling effects, as supported by the increase in plasma cGMP[27] (Figure 6.1). Moreover, while omapatrilat is a blocker of three main enzymes involved in bradykinin degradation (ACE, APP and NEP), sacubitril/valsartan only inhibits one (NEP). The half-lives of LBQ657 and valsartan are similar at 12 hours and 14 hours, respectively, allowing for twice daily administration. Bioavailability is around $60 \%$ and $25 \%$ for sacubitril and valsartan respectively. Specifically, the valsartan moiety in sacubitril/ valsartan appears to be significantly more bioavailable than what would be expected by equimolar amount of valsartan as an individual drug.[28]

\section{Sacubitril/valsartan in heart failure with reduced ejection fraction: the PARADIGM-HF trial}

The PARADIGM (Prospective Comparison of ARNI with ACE-I to Determine Impact on Global Mortality and Morbidity in Heart 
Table 1.

\begin{tabular}{|c|c|c|c|c|c|}
\hline Trial & Drug & Main inclusion criteria & $\begin{array}{l}\text { Number } \\
\text { of subject }\end{array}$ & Impact on primary end-points & Reference \\
\hline \multicolumn{6}{|c|}{ ACE inhibitors } \\
\hline CONSENSUS & Enalapril & $\begin{array}{l}\text { Congestive HF, NYHA IV, } \\
\text { cardiomegaly on chest X-ray }\end{array}$ & 253 & $\begin{array}{l}\text { Reduction in all-cause mortality }(40 \% \text { at } 6 \text { months, } \\
p=0.002 ; 31 \% \text { at } 12 \text { months, } p=0.001)\end{array}$ & $\begin{array}{l}\text { CONSENSUS Trial Study } \\
\text { Group, 1987[44] }\end{array}$ \\
\hline $\begin{array}{l}\text { SOLVD } \\
\text { Treatment }\end{array}$ & Enalapril & $\begin{array}{l}\text { LVEF } \leq 35 \% ; \text { NYHA I-IV } \\
\text { (90\% NYHA II-III) }\end{array}$ & 2569 & $\begin{array}{l}16 \% \text { reduction in all-cause mortality }(p=0.004) \text {, and } \\
26 \% \text { reduction in combined all-cause mortality and HF } \\
\text { hospitalization rate }(p<0.0001)\end{array}$ & $\begin{array}{l}\text { SOLVD Investigators, } \\
1991[45]\end{array}$ \\
\hline $\begin{array}{l}\text { SOLVD } \\
\text { Prevention }\end{array}$ & Enalapril & LVEF $\leq 35 \%$; NYHA I-II & 4228 & $\begin{array}{l}8 \%, \text { non significant, reduction in all-cause mortality } \\
(p=0.30) ; 29 \% \text { risk reduction of the combined of death } \\
\text { and HF hospitalizations }(p<0.001)\end{array}$ & $\begin{array}{l}\text { SOLVD Investigators, } \\
\text { 1992[46] }\end{array}$ \\
\hline ATLAS & Lisinopril & LVEF $\leq 30 \%$; NYHA II-IV & 3164 & $\begin{array}{l}\text { Non significant reduction in all-cause mortality }(8 \% \text {, } \\
p=0.13) \text { and in cardiovascular mortality }(10 \%, p=0.07) \text {; } \\
15 \% \text { reduction in all-cause mortality or HF hospitalization } \\
\text { rate }(p<0.001)\end{array}$ & $\begin{array}{l}\text { Packer } M \text { et al, } \\
1999[47]\end{array}$ \\
\hline \multicolumn{6}{|l|}{ ARBs } \\
\hline $\begin{array}{l}\text { CHARM- } \\
\text { Added }\end{array}$ & Candesartan & $\begin{array}{l}\text { LVEF } \leq 40 \%, \text { NYHA II-IV, } \\
\text { treatment with ACE-I }\end{array}$ & 2548 & $\begin{array}{l}15 \% \text { reduction in rate of combined cardiovascular } \\
\text { mortality or HF hospitalization }(p=0.01)\end{array}$ & $\begin{array}{l}\text { McMurray JJV et al, } \\
\text { 2003[48] }\end{array}$ \\
\hline $\begin{array}{l}\text { CHARM- } \\
\text { Alternative }\end{array}$ & Candesartan & $\begin{array}{l}\text { LVEF } \leq 40 \%, \text { NYHA II-IV, } \\
\text { intolerant to ACE-I }\end{array}$ & 2028 & $\begin{array}{l}23 \% \text { reduction in rate of combined cardiovascular } \\
\text { mortality or HF hospitalization rate }(p=0.01)\end{array}$ & $\begin{array}{l}\text { Granger CB et al, } \\
2003[49]\end{array}$ \\
\hline Val-HeFT & Valsartan & $\begin{array}{l}\text { LVEF }<40 \%, \text { NYHA II-IV, } \\
\text { treatment with ACE-I } \\
\text { LVID }>2.9 \mathrm{~cm} / \mathrm{BSA}\end{array}$ & 5010 & $\begin{array}{l}\text { Reduction in the combined endpoint of all-cause death, } \\
\text { cardiac arrest with resuscitation, HF hospitalization, or } \\
\text { i.v. administration of inotropes/vasodilators for } \geq 4 \text { hours } \\
\text { without hospitalization by } 13 \%(p=0.009) \text {; no difference } \\
\text { in all-cause mortality }\end{array}$ & $\begin{array}{l}\text { Cohn JN et al, } \\
2001[16]\end{array}$ \\
\hline
\end{tabular}

Summary of major clinical trials testing the effects of angiotensin-converting enzyme inhibitors (ACE-Is) and angiotensin II type I receptor blockers (ARBs) in patients with heart failure and/or left ventricular dysfunction. BSA, body surface area; HF, heart failure; LVEF, left ventricular ejection fraction; LVID, left ventricular inner dimension; NYHA, New York Heart Association.

Failure) trial was designed to test the hypothesis that sacubitril/ valsartan could result in reduced morbidity and mortality in patients with HFrEF in comparison to ACE-I therapy alone.[29] Inclusion criteria were NYHA functional class II-IV, LV ejection fraction, LVEF $\leq 40 \%$, plasma BNP $\geq 150 \mathrm{pg} / \mathrm{mL}$ (or NT-proBNP $\geq 600 \mathrm{pg} / \mathrm{mL}$ ), or a BNP $\geq 100 \mathrm{pg} / \mathrm{mL}$ (or NT-proBNP $\geq 400 \mathrm{pg} / \mathrm{mL}$ ) if the patient was previously hospitalized for HF within the last 12 months. Further inclusion criteria at screening were estimated glomerular filtration rate (eGFR) $\geq 30 \mathrm{~mL} / \mathrm{min} / 1.73 \mathrm{~m} 2$, systolic blood pressure $\geq 100 \mathrm{mmHg}$, and potassium $\leq 5.2 \mathrm{mmol} / \mathrm{L}$. The primary endpoint was the composite of cardiovascular mortality or HF hospitalization; secondary endpoints included time to worsening of renal function and all-cause mortality.

The PARADIGM trial had a unique study design, with a singleblind active run-in period designed to assess the tolerability of both comparator study drugs. Once having completed the runin phase, patients were randomly assigned to receive sacubitril/ valsartan $200 \mathrm{mg}$ b.i.d. or enalapril $10 \mathrm{mg} \mathrm{b.i.d.} \mathrm{in} \mathrm{a} \mathrm{double-}$ blind fashion.

The trial finally enrolled 8442 patients in 47 countries from all over the world, thus qualifying as the largest study performed in patients with HFrEF so far. After a median follow-up of 27 months, the study was prematurely stopped according to the pre-specified regulations of the Data Monitoring Committee, as interim safety and efficacy data had indicated a significant

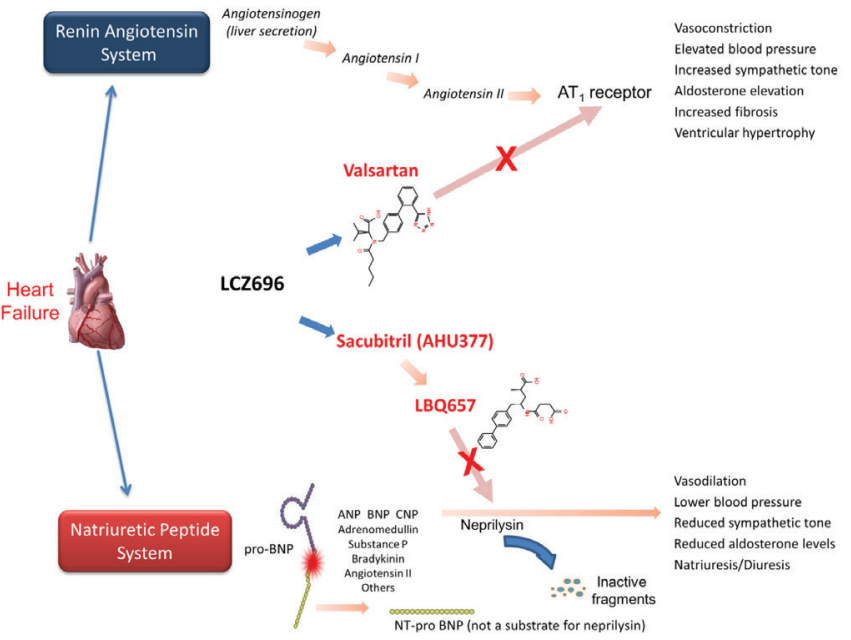

Figure 1. Schematic showing the mechanism of action of sacubitril/valsartan. The valsartan moiety blocks the angiotensin type I receptor; sacubitril is converted to the active neprilysin inhibitor LBQ657, which inhibits neprilysin. ANP, atrial natriuretic peptide; AT1, angiotensin type I; BNP, B-type natriuretic peptide; CNP, C-type natriuretic peptide; NT-proBNP, N-terminal pro-BNP. Reprinted with permission from reference 28 . 
reduction in both the primary endpoint and in cardiovascular death. The final results demonstrated that sacubitril/valsartan reduced by $20 \%$ the relative risk of cardiovascular death or HF hospitalization compared to enalapril (hazard ratio, HR, 0.80; 95\% Cl: $0.73-0.87 ; p<0.0001)$. The analysis of the treatment effects on each single component of the primary end-point was consistent with a significant reduction of the relative risk of either cardiovascular death (HR 0.80; IC 95\% 0.71-0.89; $\mathrm{p}<0.0001$ ) or HF hospitalizations (HR 0.79; IC 95\% 0.71-0.89; $\mathrm{p}<0.0001$ ) in the arm randomized to sacubitril/valsartan.[29] Finally, the secondary end-point of all-cause mortality was also reduced by $16 \%$ (HR 0.84; 95\% Cl 0.76, 0.93; $\mathrm{p}<0.0002$ ). These findings were consistent across all pre-specified subgroups.

As concerns the safety profile, elevations in serum creatinine $(\geq 2.5$ $\mathrm{mg} / \mathrm{dl}$ ) or potassium ( $\geq 6 \mathrm{mmol} / \mathrm{l}$ ), and cough were less common, whilst hypotension occurred more frequently in patients receiving sacubitril/valsartan. Of note, serious angioedema was rare and non-significant between treatment groups.

\section{Sacubitril/valsartan in the heart failure therapeutic armamentarium}

The results of PARADIGM-HF trial represent the most significant breakthrough in the management of HF of the last decade. For the first time after the successful introduction of drugs acting on neurohormonal activation, the conceptual framework in HF therapeutics has shifted from neurohomonal antagonism to neurohormonal modulation, with the combined blockade of detrimental effects of RAAS and the potentiation of the NP system.

A number of subsequent pieces of evidence have provided further insight into the benefits of sacubitril/valsartan in patients with $\mathrm{HFrEF}$, for example as concerns quality of life assessed by the Kansas City Cardiomyopathy Questionnaire[30], the reduction in recurrent HF hospitalizations and/or cardiovascular death[31], and the early benefit in prevention of sudden cardiac death.[32] Following the overwhelming statistical evidence of efficacy, sacubitril/valsartan was given regulatory approval for use in patients who conform to the main inclusion criteria of the trial. $[33,34]$ Also, the latest guidelines of ESC and of the American College of Cardiology (ACC) have both acknowledged a Class I, level of evidence $B$ recommendation for sacubitril/valsartan to reduce the risk of $\mathrm{HF}$ hospitalisation and death in HFrEF patients who remain symptomatic despite treatment with an ACE-I or ARB, a beta-blocker and MRA, albeit providing the patients would have satisfied the inclusion and exclusion criteria of the PARADIGM-HF trial.[15,35]

There is more limited evidence supporting the use of sacubitril/ valsartan as a first line therapy in patients with HFrEF who are ACEi/ARB naïve, although a few were enrolled in the TITRATION trial (a study examining two initiation and up-titration regimens for sacubitril/valsartan) reporting equivalent rates of adverse events to the total population.[36] Furthermore, the safety and feasibility of initiation of sacubitril/valsartan in-hospital or shortly after discharge in patients with de novo or acutely decompensated HFrEF has been recently demonstrated by the TRANSITION trial.[37,38]

Clinical monitoring of patients receiving sacubitril/valsartan is also a matter of debate, as only BNP, but not NT-proBNP, is a substrate of NEP and may remain elevated or transiently increase following drug initiation. NT-proBNP measurement has therefore been suggested in the context of ARNI therapy when the estimation of an NP type biomarker is desired for patient follow-up.[39]

\section{The future of combined RAAS/NEP inhibition}

As neurohormonal deregulation represents one of the main pathophysiological determinants of the underlying mechanisms of $L V$ remodelling and end-organ damage which are common to several cardiovascular diseases, sacubitril/valsartan has been tested in a number of large studies in clinical settings different from HFrEF, with two in particular of potentially major importance. The first is the PARAGON-HF trial, which showed no significant benefit of sacubitril/valsartan vs. valsartan in patients with HF and LVEF of $45 \%$ or higher.[40] The second is the PARADISE-MI, testing sacubitril/valsartan vs. ramipril in patients with LV systolic dysfunction and/or pulmonary congestion after acute myocardial infarction.[41]

Finally, sacubitril/valsartan has been predicted to achieve an indication in patients at risk for developing HF, including those with arterial hypertension[42] and, possibly, in patients with chronic kidney disease, given the results of a post-hoc analysis of the PARADIGM-HF trial demonstrating a slower rate of decrease in the eGFR in patients randomized to receive ARNI.[43]

\section{Declarations of interest}

The authors declare no conflict of interest.

\section{Acknowledgements}

The authors state that they abide by the authors' responsibilities and ethical publishing guidelines of the International Cardiovascular Forum Journal.[50]

\section{References}

1. Cohn JN, Levine TB, Francis GS, Goldsmith S. Neurohumoral control mechanisms in congestive heart failure. Am Heart J. 1981;102:509-514.

2. Braunwald E. Heart failure. JACC Heart Fail. 201;1:1-20.

3. Volpe M, Carnovali M, Mastromarino V. The natriuretic peptides system in the pathophysiology of heart failure: from molecular basis to treatment. Clin Sci (Lond). 2016;130:57-77.

4. Clerico A, Recchia FA, Passino C, Emdin M. Cardiac endocrine function is an essential component of the homeostatic regulation network: physiological and clinical implications. Am J Physiol Heart Circ Physiol. 2006;290:H17-29.

5. de Lemos JA, McGuire DK, Drazner $\mathrm{MH}$. B-type natriuretic peptide in cardiovascular disease. Lancet. 2003;362:316-22.

6. Ferro CJ, Spratt JC, Haynes WG, Webb DJ. Inhibition of neutral endopeptidase causes vasoconstriction of human resistance vessels in vivo. Circulation. 1998;97:2323-2330.

7. Bayes-Genis A, Morant-Talamante N, Lupón J. Neprilysin and Natriuretic Peptide Regulation in Heart Failure. Curr Heart Fail Rep. 2016;13:151-7.

8. Komajda M, Böhm M, Borer JS, Ford I, Tavazzi L, Pannaux M, Swedberg K. Incremental benefit of drug therapies for chronic heart failure with reduced ejection fraction: a network meta-analysis. Eur J Heart Fail. 2018;20:13151322.

9. Frankenstein L, Zugck C, Schellberg D, Nelles M, Froehlich H, Katus $H$ Remppis A. Prevalence and prognostic significance of adrenergic escape during chronic beta-blocker therapy in chronic heart failure. Eur $\mathrm{J}$ Heart Fail. 2009;11:178-184.

10. Vergaro G, Emdin M, lervasi A, Zyw L, Gabutti A, Poletti R, Mammini C, Giannoni A, Fontana M, Passino C. Prognostic value of plasma renin activity in heart failure. Am J Cardiol. 2011;108:246-251.

11. Vergaro G, Fatini C, Sticchi E, Vassalle C, Gensini G, Ripoli A, Rossignol P, Passino C, Emdin M, Abbate R. Refractory hyperaldosteronism in heart failure is associated with plasma renin activity and angiotensinogen polymorphism. J Cardiovasc Med (Hagerstown). 2015;16:416-422. 
12. Dell'Italia L, Sabri A. Activation of the renin-angiotensin system in hypertrophy and heart failure. In Heart Failure: A Companion to Braunwald's Heart Disease 2004:129-143.

13. Pfeffer MA, Braunwald E, Moyé LA, Basta L, Brown EJ Jr, Cuddy TE, Davis BR, Geltman EM, Goldman S, Flaker GC, et al. Effect of captopri on mortality and morbidity in patients with left ventricular dysfunction after myocardial infarction. Results of the survival and ventricular enlargement trial. The SAVE Investigators. N Engl J Med. 1992;327:669-677.

14. Konstam MA, Rousseau MF, Kronenberg MW, Udelson JE, Melin J, Stewart D, Dolan N, Edens TR, Ahn S, Kinan D. Effects of the angiotensin converting enzyme inhibitor enalapril on the long-term progression of left ventricular dysfunction in patients with heart failure. SOLVD Investigators. Circulation 1992;86:431-438

15. Ponikowski P, Voors AA, Anker SD, Bueno H, Cleland JGF, Coats AJS, Falk V, González-Juanatey JR, Harjola VP, Jankowska EA, Jessup M, Linde C, Nihoyannopoulos P, Parissis JT, Pieske B, Riley JP, Rosano GMC, Ruilope LM, Ruschitzka F, Rutten FH, van der Meer P; ESC Scientific Document Group. 2016 ESC Guidelines for the diagnosis and treatment of acute and chronic heart failure: The Task Force for the diagnosis and treatment of acute and chronic heart failure of the European Society of Cardiology (ESC) - Developed with the special contribution of the Heart Failure Association (HFA) of the ESC. Eur Heart J. 2016;37:2129-2200.

16. Cohn JN, Tognoni G; Valsartan Heart Failure Trial Investigators. A randomized trial of the angiotensin-receptor blocker valsartan in chronic heart failure. N Engl J Med. 2001;345:1667-1675.

17. Lang CC, Motwani J, Coutie WJ, Struthers AD. Influence of candoxatril on plasma brain natriuretic peptide in heart failure. Lancet 1991;338-255.

18. Cleland JG, Swedberg K. Lack of efficacy of neutral endopeptidase inhibitor ecadotril in heart failure. The International Ecadotril Multi-centre Dose-ranging Study Investigators. Lancet 1998;351:1657-1658.

19. Packer M, Califf RM, Konstam MA, Krum H, McMurray JJ, Rouleau JL, Swedberg K. Comparison of omapatrilat and enalapril in patients with chronic heart failure: the Omapatrilat Versus Enalapril Randomized Trial of Utility in Reducing Events (OVERTURE). Circulation. 2002;106:920-926.

20. Kaplan AP. Angioedema. World Allergy Organ J. 2008;1:103-113.

21. Cosentino F, Savoia C, De Paolis P, Francia P, Russo A, Maffei A, Venturelli V, Schiavoni M, Lembo G, Volpe M. Angiotensin II type 2 receptors contribute to vascular responses in spontaneously hypertensive rats treated with angiotensin II type 1 receptor antagonists. Am J Hypertens. 2005;18:493-499.

22. McMurray JJ. Neprilysin inhibition to treat heart failure: a tale of science, serendipity, and second chances. Eur J Heart Fail. 2015;17:242-7.

23. Katsanos S, Bistola V, Parissis JT. Combining angiotensin II receptor 1 antagonism and neprilysin inhibition for the treatment of heart failure. Expert Rev Clin Pharmacol. 2016;29:1-11.

24. Gu J, Noe A, Chandra P, Al-Fayoumi S, Ligueros-Saylan M, Sarangapani R, Maahs S, Ksander G, Rigel DF, Jeng AY, Lin TH, Zheng W, Dole WP. Pharmacokinetics and pharmacodynamics of LCZ696, a novel dual-acting angiotensin receptor-neprilysin inhibitor (ARNi). J Clin Pharmacol. 2010 Apr;50(4):401-14. doi: 10.1177/0091270009343932.

25. Feng L, Karpinski PH, Sutton P, Liu Y, Hook DF, Hu B, et al. LCZ696: a dual-acting sodium supramolecular complex. Tetrahedron Letters 2012;53:275-276.

26. Flarakos J, Du Y, Bedman T, Al-Share Q, Jordaan P, Chandra P, Albrecht D, Wang L, Gu H, Einolf HJ, Huskey SE, Mangold JB. Disposition and metabolism of [(14)C] Sacubitril/Valsartan (formerly LCZ696) an angiotensin receptor neprilysin inhibitor, in healthy subjects. Xenobiotica. 2016;46:986-1000.

27. Kobalava Z, Kotovskaya Y, Averkov O, Pavlikova E, Moiseev V, Albrecht D, Chandra P, Ayalasomayajula S, Prescott MF, Pal P, Langenickel TH, Jordaan P, Rajman I. Pharmacodynamic and Pharmacokinetic Profiles of Sacubitril/Valsartan (LCZ696) in Patients with Heart Failure and Reduced Ejection Fraction. Cardiovasc Ther. 2016;34:191-198.

28. Vardeny O, Miller R, Solomon SD. Combined neprilysin and reninangiotensin system inhibition for the treatment of heart failure. JACC Heart Fail. 2014;2:663-670.

29. McMurray JJ, Packer M, Desai AS, Gong J, Lefkowitz MP, Rizkala AR, Rouleau JL, Shi VC, Solomon SD, Swedberg K, Zile MR; PARADIGM-HF Investigators and Committees. Angiotensin-neprilysin inhibition versus enalapril in heart failure. N Engl J Med. 2014;371:993-1004.

30. Lewis EF, Claggett BL, McMurray JJV, Packer M, Lefkowitz MP, Rouleau JL, Liu J, Shi VC, Zile MR, Desai AS, Solomon SD, Swedberg K. Health-Related Quality of Life Outcomes in PARADIGM-HF. Circ Heart Fail. 2017;10.

31. Mogensen UM, Gong J, Jhund PS, Shen L, Køber L, Desai AS, Lefkowitz MP, Packer M, Rouleau JL, Solomon SD, Claggett BL, Swedberg K, Zile MR, Mueller-Velten G, McMurray JJV. Effect of sacubitril/valsartan on recurrent events in the Prospective comparison of ARNI with ACEI to Determine Impact on Global Mortality and morbidity in Heart Failure trial (PARADIGM-HF). Eur J Heart Fail. 2018;20:760-768.

32. Desai AS, McMurray JJ, Packer M, Swedberg K, Rouleau JL, Chen F, Gong J,cRizkala AR, Brahimi A, Claggett B, Finn PV, Hartley LH, Liu J, Lefkowitz M, Shi V, Zile MR, Solomon SD. Effect of the angiotensin-receptor-neprilysin inhibitor LCZ696 compared with enalapril on mode of death in heart failure patients. Eur Heart J. 2015;36:1990-1997.
33. European Medicines Agency, ENTRESTO: EPAR Product information, (2015) http://www.ema.europa.eu/docs/en_GB/document_library/EPAR_Product_Information/human/004062/WC500197536.pdf (accessed March $5,2018)$

34. U.S. Food and Drug Administration, ENTRESTO (sacubitril and valsartan. Highlights of prescribing information, (2015). https://www.accessdata. fda.gov/drugsatfda docs/label/2015/2076200rig1s000lbl.pdf (accessed March 5, 2018).

35. Yancy CW, Jessup M, Bozkurt B, Butler J, Casey DE Jr, Colvin MM, Drazner $\mathrm{MH}$, Filippatos GS, Fonarow GC, Givertz MM, Hollenberg SM, Lindenfeld J, Masoudi FA, McBride PE, Peterson PN, Stevenson LW, Westlake C. 2017 ACC/AHA/HFSA Focused Update of the 2013 ACCF/AHA Guideline for the Management of Heart Failure: A Report of the American College of Cardiology/American Heart Association Task Force on Clinical Practice Guidelines and the Heart Failure Society of America. Circulation. 2017;136:e137-e161.

36. Senni M, McMurray JJ, Wachter R, Mclntyre HF, Reyes A, Majercak I, Andreka P, Shehova-Yankova N, Anand I, Yilmaz MB, Gogia H, MartinezSelles M, Fischer S, Zilahi Z, Cosmi F, Gelev V, Galve E, Gómez-Doblas JJ, Nociar J, Radomska M, Sokolova B, Volterrani M, Sarkar A, Reimund B, Chen F, Charney A. Initiating sacubitril/valsartan (LCZ696) in heart failure: results of TITRATION, a double-blind, randomized comparison of two uptitration regimens. Eur J Heart Fail. 2016;18:1193-1202.

37. Pascual-Figal D, Wachter R, Senni M, Belohlavek J, Noè A, Carr D, Butylin D. Rationale and design of TRANSITION: a randomized trial of predischarge vs. post-discharge initiation of sacubitril/valsartan. ESC Heart Fail. 2018;5:327-336.

38. Senni M, Wachter R, Belohlavek J, Witte K, Strabuzynska-Migaj E, Kobalava Z, Fonseca C, Noe A, Butylin D, Schwende H, Pascual-Figal D. P6531 Initiation of sacubitril/valsartan in hospitalized patients with HFrEF after hemodynamic stabilization: baseline characteristics of the TRANSITION study compared with TITRATION and PARADIGM-HF. Eur Heart J. 2018;39:.P6531

39. Maisel AS, Daniels LB, Anand IS, McCullough PA, Chow SL. Utility of natriuretic peptides to assess and manage patients with heart failure receiving angiotensin receptor blocker/neprilysin inhibitor therapy. Postgrad Med. 2018;130:299-307.

40. Solomon SD, McMurray JJV, Anand IS, et al. Angiotensin-neprilysin inhibition in heart failure with preserved ejection fraction. $N$ Engl J Med 2019 Sep 1; [e-pub]. (https://doi.org/10.1056/NEJMoa1908655).

41. ClinicalTrials.gov ID NCT02924727

42. Ruilope LM, Dukat $A$, Böhm M, Lacourcière $Y$, Gong J, Lefkowitz MP. Blood-pressure reduction with LCZ696, a novel dual-acting inhibitor of the angiotensin II receptor and neprilysin: a randomised, double-blind, placebo-controlled, active comparator study. Lancet. 2010;375:1255-1266.

43. Damman K, Gori M, Claggett B, Jhund PS, Senni M, Lefkowitz MP Prescott MF, Shi VC, Rouleau JL, Swedberg K, Zile MR, Packer M, Desai AS, Solomon SD, McMurray JJV. Renal Effects and Associated Outcomes During Angiotensin-Neprilysin Inhibition in Heart Failure. JACC Heart Fail. 2018;6:489-498.

44. CONSENSUS Trial Study Group. Effects of enalapril on mortality in severe congestive heart failure. Results of the Cooperative North Scandinavian Enalapril Survival Study (CONSENSUS). N Engl J Med. 1987;316:14291435

45. SOLVD Investigators. Effect of enalapril on survival in patients with reduced left ventricular ejection fractions and congestive heart failure. N Engl J Med 1991;325:293-302.

46. SOLVD Investigators. Effect of enalapril on mortality and the development of heart failure in asymptomatic patients with reduced left ventricular ejection fractions. N Engl J Med. 1992;327:685-691.

47. Packer M, Poole-Wilson PA, Armstrong PW, Cleland JGF, Horowitz JD, Massie BM, Ryden L, Thygesen K, Uretsky BF, Ryde'n L, Thygesen K, Uretsky BF, ATLAS Study Group. Comparative effects of low and high doses of the angiotensin-converting enzyme inhibitor, lisinopril, on morbidity and mortality in chronic heart failure. Circulation 1999;100:2312-2318.

48. McMurray JJV, Ostergren J, Swedberg K, Granger CB, Held P, Michelson EL, Olofsson B, Yusuf S, Pfeffer MA. Effects of candesartan in patients with chronic heart failure and reduced left-ventricular systolic function taking angiotensin-converting-enzyme inhibitors: the CHARM-Added trial. Lancet 2003;362:767-771.

49. Granger CB, McMurray JJV, Yusuf S, Held P, Michelson EL, Olofsson B, Ostergren J, Pfeffer MA, Swedberg K. Effects of candesartan in patients with chronic heart failure and reduced left-ventricular systolic function intolerant to angiotensin-converting-enzyme inhibitors: the CHARMAlternative trial. Lancet 2003;362:772-776.

50. Shewan LG, Coats AJS, Henein MY. Authors' Responsibilities and Ethical Publishing. International Cardiovascular Forum Journal 2018;13:3-4, DOI: $10.17987 /$ icfj.v13i0.525 